\title{
Opportunities to Manage Herbicide Resistance through Area-Wide Management: Lessons from Australian Cropping Regions
}

\author{
Kaitlyn Height*iD, Sonia Graham (D), Rebecca Campbell, Gina Hawkes, Silja Schrader, Louise Blessington \\ and Scott McKinnon
}

check for updates

Citation: Height, K.; Graham, S.; Campbell, R.; Hawkes, G.; Schrader, S.; Blessington, L.; McKinnon, S. Opportunities to Manage Herbicide Resistance through Area-Wide Management: Lessons from Australian Cropping Regions. Sustainability 2022, 14, 1793. https://doi.org/10.3390/su14031793 Academic Editor: Roberto Mancinelli

Received: 15 December 2021

Accepted: 2 February 2022

Published: 4 February 2022

Publisher's Note: MDPI stays neutral with regard to jurisdictional claims in published maps and institutional affiliations.

Copyright: (c) 2022 by the authors. Licensee MDPI, Basel, Switzerland. This article is an open access article distributed under the terms and conditions of the Creative Commons Attribution (CC BY) license (https:// creativecommons.org/licenses/by/ $4.0 /)$.

\author{
School of Geography and Sustainable Communities, University of Wollongong, \\ Wollongong, NSW 2522, Australia; sgraham@uow.edu.au (S.G.); crebecca@uow.edu.au (R.C.); \\ ghawkes@uow.edu.au (G.H.); silja@uow.edu.au (S.S.); louise.blessington@anu.edu.au (L.B.); \\ scottmck@uow.edu.au (S.M.) \\ * Correspondence: kheight@uow.edu.au
}

\begin{abstract}
Herbicide resistance management is often understood as a decision for individual land managers, but their decisions have far-reaching impacts for social-ecological systems. Area-wide management can reduce these impacts by supporting many land managers to cooperatively work towards a shared goal of reducing the spread of resistance. The aim of this research is to identify what support is needed for area-wide herbicide resistance management in cropping systems. Data was collected from 84 interviews with growers, public land managers and weed management advisors. Sixty-five interviews were conducted across three cropping regions of eastern Australia-Darling Downs (Queensland), Riverina (New South Wales) and Sunraysia (Victoria)—and 19 interviews were conducted with stakeholders beyond these regions. The majority (51\%) of interviewees expressed concern about the spread of herbicide resistance, but only $14 \%$ described involvement in areawide resistance management programs. Area-wide management was mostly reported to involve sharing information among stakeholders, rather than coordination or joint activities. Key barriers to participation were perceived to be the diverse agricultural industries in each region and the costs of participation. Future area-wide management program designs need to build working relationships among diverse stakeholders, clearly define the boundaries of the program and demonstrate the benefits that accrue from participation.
\end{abstract}

Keywords: community management; collective action; participation; invasive species management; biosecurity; grower cooperation; area-wide control; cooperative weed management

\section{Introduction}

Herbicide-resistant weeds are becoming more common around the world, affecting which crops are grown, how weeds are managed and farm profitability [1,2]. According to the International Herbicide-Resistant Weed Database, Australia is second only to the USA with respect to the number of resistant weeds in the country [3]; Australia has 49 herbicide-resistant weed species. Australia also has the most extensive evolution of weed populations with resistance to multiple herbicides across grain producing regions [2].

The consequences of such high rates of herbicide resistance in Australia are reflected in changes to farming practices. Grain growers' adoption of integrated weed management practices is strongly associated with herbicide resistance status [4]. More than nine-tenths (94\%) of grain growers adopt additional management practices to prevent and manage herbicide resistance [5]. These practices include herbicide rotation, double knockdown (use of a different second treatment to kill any survivors), changing herbicide application rates and methods, cultivation, weed seed control and harvest, and burning, among others. The use of such practices has resulted in some success in limiting the loss of effective 
herbicides and preventing development of further resistance [6], with some claiming that Australia is now a global leader in herbicide resistance management (e.g., [2]). Yet, herbicide resistance is costing Australian grain growers AUD 187 million annually in additional herbicide costs alone and more than two-thirds (43\%) of grain growers believe that due to seed and pollen movement they will have glyphosate-resistant weed populations on their farms in 10 years' time, regardless of whether they stop using glyphosate [5]. While current evidence suggests that herbicide resistance tends to expand in range via repeated evolutions more often than seed mobility (e.g., [7]), growers' concerns reflect the potential for herbicide-resistant weeds to spread across the landscape (e.g., [8]). Therefore, management of herbicide resistance may require a new approach that goes beyond applying best management practices at the farm scale [9].

Over the last decade, researchers have begun to recognise that management of herbicide-resistant weeds represents a collective action problem that requires cross-property collaboration [10,11]. Preservation of herbicide susceptibility is a collective action problem because it requires all land managers to diversify their management actions [1]. If most land managers invest in herbicide resistance management, benefits will also accrue to land managers who do not contribute. In addition, if a small number of land managers repeatedly apply the same herbicides they will create or exacerbate herbicide resistance problems on their property, which could spread to neighbouring properties and undermine their efforts. Past research has identified a number of strategies that can be used to encourage land managers to work together on herbicide resistance. These strategies involve clearly defining the boundaries of the area in which herbicide-resistant weeds will be managed, having land managers within that area agreeing to a shared goal, providing support to land managers who have fewer resources for managing herbicide-resistant weeds, and building strong working relationships among land managers [1].

To date, there has been limited empirical research on collective approaches to managing herbicide-resistant weeds. In a recent synthesis of social science research on collective action in invasive species management, Graham et al. [12] found only 19 articles that reported on collective action related to weed management, most of which focused on weed management in grazing systems. Only one article considered collective management of herbicide-resistant weeds in cropping systems (i.e., [11]). Since then, Ervin et al. [13] have published a further article exploring farmer attitudes toward cooperative approaches to herbicide resistance management. They found that farmers were more likely to believe that effective management of weed resistance requires cooperation among farmers, a precursor to collective action, if they were concerned about multiple resistant weeds and weed mobility, and if they believed that other growers and extension educators are important for developing weed management approaches. We know of no research that has sought to understand whether and how growers participate in collective action for herbicide resistance management in Australia.

Social research on other collective action problems in cropping areas, such as management of insects and pests, suggests area-wide management (AWM) as a solution. Areawide management represents a specific type of collective action that involves groups of neighbouring growers jointly applying a particular approach, such as integrated pest management [14], multiple times [15] across ecosystems, rather than focusing on individual farms [16]. Examples of joint activities undertaken by land managers include collectively scouting for pests [17], sharing machinery [18], synchronised cropping [19-21], coordinated timing of pesticide application [22,23] or the release of biological controls [19]. External organisations, such as government agencies (e.g., [16]) or researchers (e.g., [14]) often lead such AWM programs.

Social research on AWM in cropping systems has identified a number of drivers and barriers to participation in AWM programs. These include demonstrating the efficacy of AWM programs [23] and the benefits land managers would receive from cooperating with their neighbours [20]. AWM also requires trust in other farmers and government staff, and is more likely among farmers who largely depend on agricultural production for their 
income and who engage agricultural extension agents for advice. Given the lack of research on AWM or collective action on herbicide resistance in Australia or internationally, little is known about whether growers would be interested in participating in collaborative community-based approaches to manage herbicide resistance and what would encourage or discourage growers from joining such programs. This project aims to address this gap through the following research questions:

1. What are the perceptions of and experiences with AWM of herbicide resistance in Australian cropping regions among growers, government staff, extension advisors and other key stakeholders?

2. What are the impediments for AWM of herbicide resistance in Australian cropping regions?

3. What is needed to encourage AWM of herbicide resistance?

\section{Materials and Methods}

This study forms part of a transdisciplinary research project involving 11 Australian research and industry organisations (see Acknowledgments for full list of organisations involved) to better understand mobility of key weeds in cropping systems, their herbicide resistance, the costs of their management and the attitudes of growers, agronomists, public land managers, industry representatives and government staff to AWM of weeds. Given the limited social science research that exists on the topic, we began with qualitative interviews to learn about how AWM is understood by diverse stakeholders.

\subsection{Case Study Areas}

The transdisciplinary project team selected three cropping regions as case studies, as follows: Darling Downs, Queensland; Riverina, New South Wales and Sunraysia, Victoria; (Figure 1). These regions were chosen because they comprise different levels of broadacre crop industry diversity (Table 1). It was also anticipated that weeds would have different dispersal patterns across different land-use types and that attitudes to AWM would differ due to distinct social dynamics in each region.

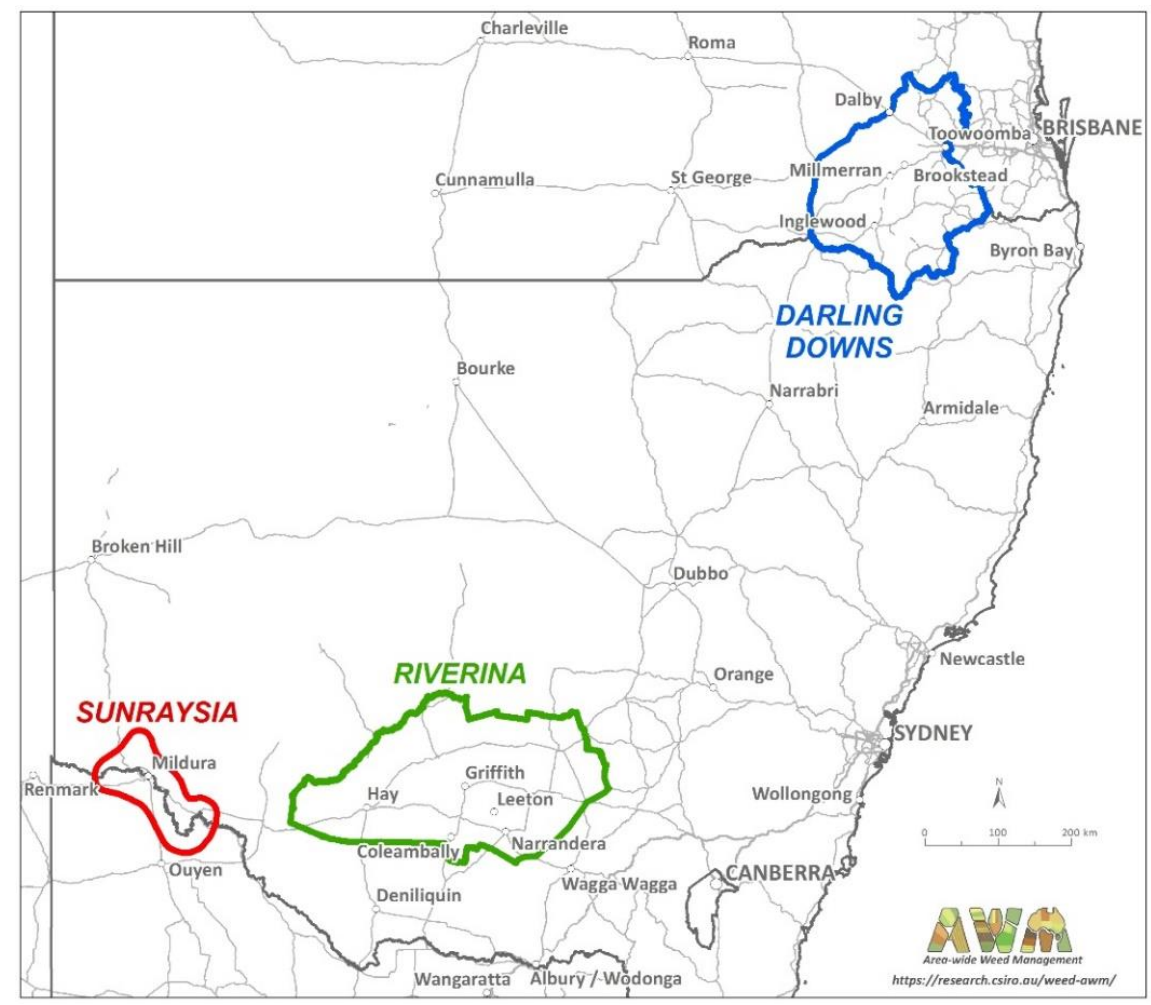

Figure 1. The three case study areas. Map produced by Christina Ratcliff at the Commonwealth Scientific and Industrial Research Organisation. 
Table 1. Agricultural and weed data for the natural resource management (NRM) region corresponding to each of the case study areas as well as the number of interviewees.

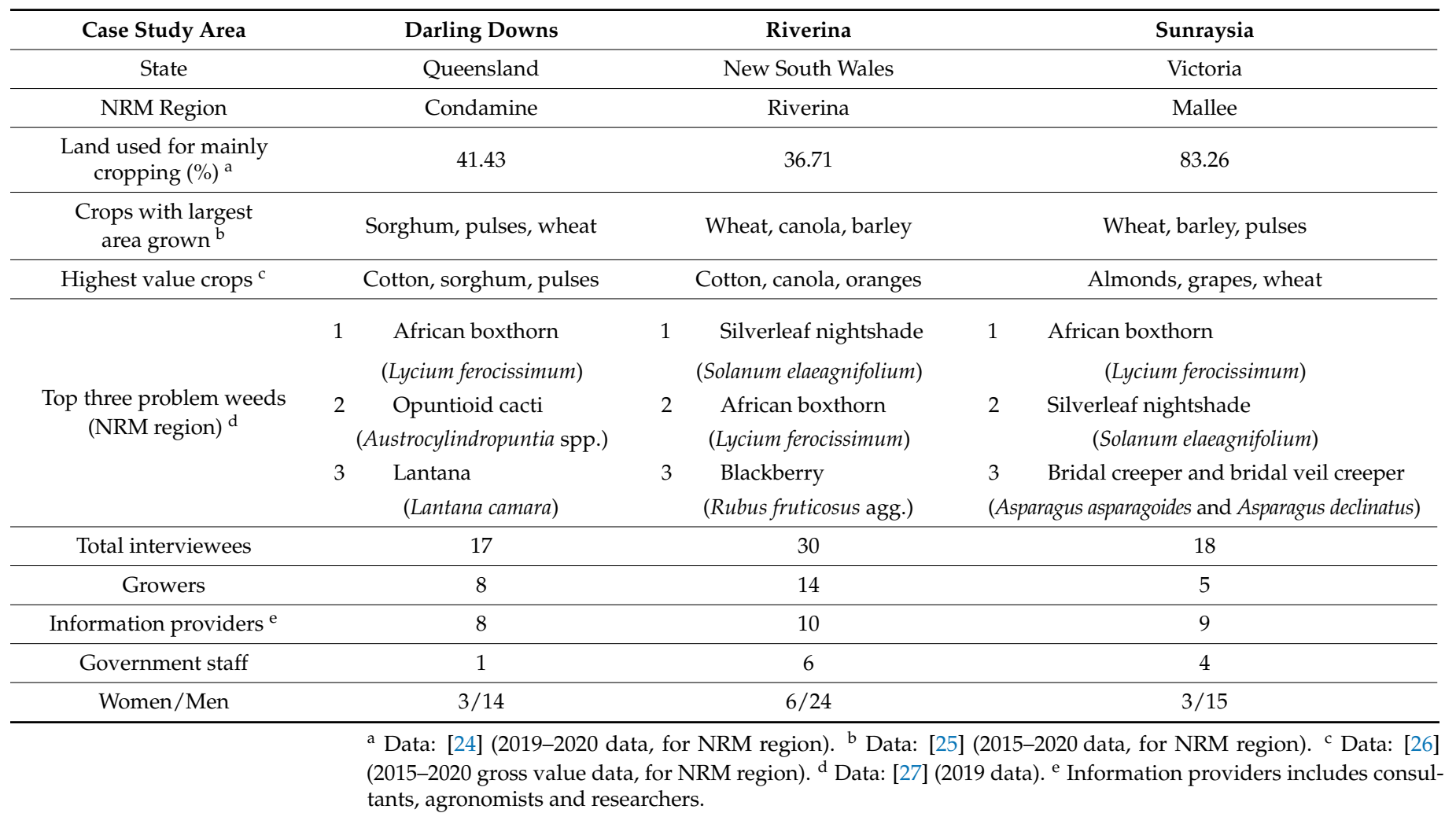

In the Darling Downs region of Queensland, the top three crops grown by area over the years 2015-2020 were sorghum, pulses and wheat, though cotton was the crop with the highest gross value (Table 1). The other major land use in the region is grazing. The Riverina region of New South Wales has the smallest proportion of land mainly used for cropping. The region is known for its irrigated rice, citrus and nut production, though cotton, canola and oranges had the highest gross value from 2015-2020. The Sunraysia region of Victoria has the highest proportion of land mainly used for cropping. This region is known for production of its two highest value crops, almonds and grapes, although the main crops by area are broadacre crops. According to a national survey of agricultural land managers about weeds on their property, African boxthorn is a key weed of concern in all three regions. In the Riverina and Sunraysia, silverleaf nightshade is also a key weed of concern (Table 1).

\subsection{Data Collection}

Semi-structured phone interviews were undertaken with 65 individuals across the case study regions (Table 1). Potential participants were identified through a combination of purposive sampling and chain referral. Purposive sampling [28] was utilised to ensure inclusion of interview participants from all major agricultural industries present in the case study areas, a range of property sizes and a variety of cropping systems. Supplementary interviews were conducted with 19 stakeholders from multiple, additional cropping regions to learn more about their experience with AWM and to understand the extent to which attitudes across the case study regions are consistent with those held by key stakeholders in other cropping regions across Australia. The supplementary interviews were held with stakeholders from the Gwydir River Catchment and surrounding area, southern Western Australia and one each from Victoria, South Australia and Tasmania. These are grouped together under the 'Other' case study. 
Interviewees were grouped according to one of the following three roles: growers $(n=30)$; information providers, which included agronomists, consultants, researchers and Landcare coordinators $(n=39)$; and government staff working for local governments or state government departments $(n=15)$. Each interviewee was asked questions about the most significant weed management issues, most concerning weeds, arrival of new weeds, working together in weed management, AWM and views about the future of weed management in their region (the full interview schedule is available as Supplementary Material Table S1). Interview questions were tailored as needed to the role and experience of each interviewee. Most questions were open-ended to provide more flexibility and opportunity for interviewees to discuss all aspects of weed management [28]. Interviews were conducted between August and December 2020, lasting between 15 and 63 minutes. Each interview was digitally recorded, transcribed and reviewed prior to coding. To protect the anonymity of participants, quotes are identified according to the region and role of the interviewee.

This study was approved by CSIRO's Social Science Human Research Ethics Committee and by the University of Wollongong Human Research Ethics Committee.

\subsection{Data Analysis}

Qualitative data analysis was conducted after interview transcripts were imported into the NVivo 12 software program. Transcripts were coded by the research team using thematic analysis [29]. The results reported in this article draw from the analysis of codes that related to understandings of AWM of weeds, and also its benefits and costs. The themes were: why AWM is needed; prerequisites for AWM; what is needed for AWM (actors, activities); what could hinder AWM; lessons from previous AWM programs; AWM and herbicide resistance. The quotes from the interviews included below are 'illustrative' [30] (p. 1104) of these themes and show how 'meanings are expressed in the respondents' own words' [31] (p. 508).

\section{Results}

When interviewees were asked about the most significant issues concerning the management of weeds in their region (Q1 in Supplementary Material), herbicide resistance was most frequently mentioned across all regions (Darling Downs, 12 of 17 interviewees; Riverina, 12 of 30 interviewees; Sunraysia, 11 of 18 interviewees; Other, 8 of 19 interviewees). Overall, herbicide resistance was mentioned five times as often as the next most concerning issue, which was competing priorities. Stakeholders were concerned about the mobility of herbicide resistance and the increased costs associated with its management.

"On-farm, obviously, resistance is something that we're always conscious of . . when it comes to chemical use, whether it be from our use or obviously a neighbour's use, that resistant seeds get across the fence line, so that's obviously one thing that we always keep in mind."

(Sunraysia, grower)

"The main issue is resistance to chemicals. We're relying on chemicals more and more now ... quite a few weeds [are] resistant to Roundup ... [it] makes everything harder than it should be ... More expensive chemicals for one, because you're putting bigger rates, and you're putting more expensive chemicals to try and pull down the weeds. And also it takes more time, so that's at a cost. It takes - and if you cultivate, it's more time again, fuel, machinery, wear and tear, so it's just a flow-on effect."

(Riverina, information provider)

"I see a big problem is glyphosate resistance ... we've got this wonderful technology of cotton that can be sprayed over the top with glyphosate, all this sort of thing, which is fantastic, but you then actually get to a point where the weeds that are being sprayed are going to build a resistance to the glyphosate, and that not only affects the industry but it has a tenfold effect on the agricultural industry. So I believe that is going to be a big problem in years to come."

(Darling Downs, information provider) 
Other stakeholders identified that herbicide resistance is problematic because it affects all land managers, including those who use integrated weed management practices, and raises questions about how herbicide-resistant weeds can be sustainably managed.

"if glyphosate suddenly is deregistered, what alternative is there to broadacre weed control? At this stage it's going to be tilling, and if it's tilling you're going to see wholesale destruction of soil, no doubt about it."

(Sunraysia, government staff)

Concern about herbicide resistance was also evident when interviewees identified the three weeds of most concern to them (Q2). The top weeds of concern identified across all interviewees (fleabane, feathertop Rhodes grass and ryegrass), as well as additional weeds, were identified as problematic because herbicide resistance is well-established or becoming evident in these weeds (Table 2).

Table 2. Number of interviewees from each case study area reporting weeds' herbicide resistance as their reason for including them among their three most concerning weeds.

\begin{tabular}{|c|c|c|c|c|c|}
\hline \multirow{2}{*}{ Weed of Concern } & \multicolumn{4}{|c|}{ Case Study Area } & \multirow{2}{*}{ TOTAL } \\
\hline & Darling Downs & Riverina & Sunraysia & Other & \\
\hline $\begin{array}{l}\text { Barnyard grass } \\
\text { (Echinochloa spp.) }\end{array}$ & 2 & 0 & 0 & 2 & 4 \\
\hline $\begin{array}{c}\text { Dirty Dora } \\
\text { (Cyperus difformis) }\end{array}$ & 0 & 1 & 0 & 0 & 1 \\
\hline $\begin{array}{l}\text { Feathertop Rhodes } \\
\text { grass (Chloris virgata) }\end{array}$ & 7 & 3 & 0 & 3 & 13 \\
\hline $\begin{array}{c}\text { Fleabane } \\
\text { (Conyza spp.) }\end{array}$ & 0 & 5 & 0 & 2 & 7 \\
\hline $\begin{array}{c}\text { Ryegrass } \\
\text { (Lolium rigidum) }\end{array}$ & 0 & 14 & 1 & 2 & 17 \\
\hline $\begin{array}{l}\text { Sow thistle, milk thistle } \\
\text { (Sonchus oleraceus) }\end{array}$ & 1 & 1 & 0 & 2 & 4 \\
\hline $\begin{array}{l}\text { Windmill grass } \\
\text { (Chloris truncata) }\end{array}$ & 0 & 0 & 0 & 1 & 1 \\
\hline
\end{tabular}

\subsection{Perceptions of AWM of Herbicide-Resistant Weeds}

While more than half ( 43 of 84 ) of the interviewees mentioned being concerned about herbicide resistance (Q1), only three mentioned a lack of collective action or AWM of herbicide resistance as an issue of concern to them. However, later interview questions about working together in weed management and understandings of AWM (Q3 and Q4) resulted in 17 interviewees describing what a collaborative or area-wide approach to herbicide resistance could be and achieve.

When interviewees were asked whether it is necessary for people to work together to manage weeds (Q3), 11 interviewees used herbicide resistance as an example of why collaboration is needed.

"we're all trying to solve some of these problems together, so if we can share some efficiencies and some gains, then you're less likely to end up with a problem of resistance, or you're less likely to end up with some problems where some weeds break out, so where it gets too big or too established to control."

(Riverina, information provider)

Twenty-one interviewees used herbicide resistance management as an example of why AWM is important (Q4, Q4a, Q4d) or what could be achieved, with one explaining the futility of not having an AWM approach: 
"[broadacre farmers] spend far too much time and herbicide spraying out troublesome weeds, and until there is an area-wide strategy that acknowledges the impact on environment and economy, then we are just, you know, we are a voice in the wilderness."

(Sunraysia, information provider)

Of these interviewees, just over half (12 of 21) described the scale at which management of herbicide resistance should occur and 10 interviewees described herbicide resistance as a shared responsibility. The need for collaboration among stakeholders to manage herbicide resistance was highlighted by interviewees where they spoke about experience of, and potential for, herbicide-resistant weeds to spread across property boundaries.

"But it's all very good for a farmer to be doing all the right things, and controlling weeds on his farm but if, just over the fence, you've got a seedbank of Roundup resistant ryegrass blowing in across your farm, or coming in in the irrigation water that you're using, well, you're fighting a losing battle."

(Riverina, grower)

Collaboration was also seen as necessary for preventing herbicide resistance itself and prolonging the time to establishment of resistance. For example, AWM of herbicide resistance was perceived as a way of encouraging a shift away from practices that contribute to the development of resistance. Interviewees described an AWM approach as more urgently needed when chemical options are being reduced and when more education or sharing of knowledge is needed.

\subsection{Experience with AWM for Herbicide-Resistant Weeds}

Twelve interviewees across all case studies, including three growers, reported involvement in some form of AWM of herbicide resistance. Three information providers had participated in programs to collect information about herbicide resistance organised by either the Grains Research and Development Corporation (GRDC) with the Australian Herbicide Resistance Initiative (AHRI) or Landcare, while the remaining nine interviewees carried out work they described as "area-wide" outside of formal programs. The most common means of participating in AWM reported was by testing seeds for herbicide resistance as part of an industry or Landcare program, or agronomists encouraging growers to do so.

"I've sent a bit of stuff away on sow thistles and stuff to get tested when there's been little projects to go on. They want samples and I'll do that sort of stuff because I need to know, so I do that sort of stuff."

(Darling Downs, information provider)

"And so GRDC along with AHRI ... they put together a bit of a plan to just collect identified weeds across the region .... And one was trying to find the extent of the resistance but also just getting people looking at that milk thistle was flying the flag for resistance management and area-wide management of weeds."

(Other, information provider)

Overall, activities reported as examples of AWM for herbicide resistance can be categorised into three main types of activities (Table 3). The first set of activities related to sharing information about herbicide-resistant weeds. This included the following: talking to neighbours about herbicide-resistant weeds; communication and extension of national research; discussing chemical use at meetings; agronomists discussing herbicide resistance with clients. The second set of activities involved on-farm practices, such as the following: encouraging integrated weed management (with biological and physical control specifically mentioned); complying with industry herbicide use guidelines; changing herbicides regularly. The third set of activities were contributions to research and included the following: getting weed samples tested for herbicide resistance; encouraging clients to get weed samples tested; offering herbicide resistance testing. 
Table 3. Examples of activities stakeholders reported as being part of area-wide management of herbicide resistance.

\begin{tabular}{|c|c|}
\hline Activity & Quote \\
\hline \multicolumn{2}{|r|}{ Sharing information } \\
\hline $\begin{array}{l}\text { Talking to neighbours about } \\
\text { herbicide resistance }\end{array}$ & $\begin{array}{l}\text { "Like with that Feathertop Rhodes grass we have, we've just said that we'd spotted it and sent } \\
\text { it off for some resistance testing and let them [neighbours] know." (Other, grower) }\end{array}$ \\
\hline $\begin{array}{l}\text { Discussing chemical use } \\
\text { at meetings }\end{array}$ & "So we will talk about weeds, like I said, and chemicals and all that sort of stuff." (Other, grower) \\
\hline $\begin{array}{l}\text { Discussing herbicide resistance } \\
\text { with clients }\end{array}$ & $\begin{array}{l}\text { "A lot of that was so that we're just advertising the fact to some of these farmers, hell, to a lot of } \\
\text { these farmers that, you know, this stuff blows in the wind and it's going to hit the farm, it's } \\
\text { going to be on your farm soon." (Other, information provider) }\end{array}$ \\
\hline $\begin{array}{l}\text { Communication and extension } \\
\text { of national research }\end{array}$ & $\begin{array}{l}\text { "I actually think we're doing quite well, maybe through organisations like AHRI over the last } \\
20 \text { years in tackling herbicide resistance, and it's probably just been multiple, ongoing } \\
\text { communication and extension of the latest research." (Other, information provider) }\end{array}$ \\
\hline \multicolumn{2}{|r|}{ On-farm practices } \\
\hline $\begin{array}{l}\text { Complying with guidelines for } \\
\text { herbicide use }\end{array}$ & $\begin{array}{l}\text { "The bones of an area of wide management approach are there with HRMS, that's the } \\
\text { Herbicide Resistance Management Strategy that's in place." (Riverina, information provider) } \\
\text { "The good thing is the recommended rate [of herbicide application] is right at the top end of a } \\
\text { very, very high rate is what they, the minimum they [producers of glyphosate tolerant cotton] } \\
\text { recommend." (Darling Downs, grower) }\end{array}$ \\
\hline $\begin{array}{l}\text { Changing herbicides } \\
\text { used regularly }\end{array}$ & $\begin{array}{l}\text { "Any system will break down if you try to do the same thing over and over again .... You've } \\
\text { got to try to mix up the system a bit, mix up the chemistry and change things around." (Darling } \\
\text { Downs, information provider) }\end{array}$ \\
\hline $\begin{array}{c}\text { Encouraging integrated } \\
\text { weed management }\end{array}$ & $\begin{array}{c}\text { "I know one thing that we do try and really push ... is integrated control methods." (Other, } \\
\text { information provider) }\end{array}$ \\
\hline \multicolumn{2}{|r|}{ Research } \\
\hline $\begin{array}{l}\text { Getting weed samples tested for } \\
\text { herbicide resistance }\end{array}$ & $\begin{array}{l}\text { "So, we've participated in a couple of thistle resistance testings. So that's on a regional basis in } \\
\text { the state, probably a whole country basis, really" (Other, information provider) }\end{array}$ \\
\hline $\begin{array}{l}\text { Encouraging clients to get weed } \\
\text { samples tested }\end{array}$ & $\begin{array}{c}\text { "So, at the moment I'm in the middle of recruiting farmers to get barley grass screened to see } \\
\text { what that's resistant to, so that is sort of highlighting differences between the areas." (Other, } \\
\text { information provider) }\end{array}$ \\
\hline $\begin{array}{l}\text { Offering herbicide } \\
\text { resistance testing }\end{array}$ & $\begin{array}{l}\text { "We have offered, as an industry, free herbicide resistance testing; so send samples in, there's } \\
\text { six weeds in that project, so you can send them in and have them tested free of charge." } \\
\text { (Riverina, information provider) }\end{array}$ \\
\hline
\end{tabular}

\subsection{Barriers to AWM of Herbicide Resistance}

Numerous barriers to AWM of herbicide resistance were recognised $(Q 4 \mathrm{~g})$, but interviewees most often explained stakeholders' unwillingness to participate in AWM of herbicide resistance through the following two reasons: the regional diversity in cropping systems (four interviewees) and growers' reluctance to disclose information about herbicide resistance on their property (four interviewees).

Growers recognised that for AWM of herbicide resistance, specific problems need to be shared among land managers. In the case study regions, a diverse range of crops are grown, so growers have neither the same herbicide resistance problems, nor the same required management actions. This makes coordination across properties difficult.

"Every grower has a completely different approach to their farming and what crops they grow and their rotations... I'm the only cotton grower in the area, basically, in this spot. So what I do on my farm in terms of resistance will be completely different to what they do."

(Darling Downs, grower)

Regardless of industry, land managers have diverse weed management priorities and practices, so vary in their willingness to spend time and money on weed management. 
Landholders may also be unwilling to share information about herbicide resistance on their property with others because it can affect the value of property, reduce the inclination of people to purchase a property with herbicide-resistant weeds and landholders can be reluctant to discuss problems on their property in general.

"Some people probably don't want others to know that they have resistance issues or hard-to-kill weeds. So, I suppose that is a barrier and people get funny about not letting other people in on what they've got on their own farm in terms of issues"

(Other, information provider)

Limiting short-term expenditure on weed management is a priority of some land managers. They may want to avoid more costly weed management or want to reduce the amount of work involved in controlling weeds, and so may be reluctant to follow herbicide resistance management advice. Two information providers recognised that the limited recognition of the long-term benefits of varying herbicides can be a barrier to greater participation in AWM of herbicide resistance. These benefits can be long-term cost savings and preventing herbicide resistance on their own or others' properties.

"they'll just use whatever's sort of cheapest and nastiest to kill the weed where I guess there's an opportunity there for them to take on more cost. But that's hard for them to justify if it - unless it can be shown to them that switching to a maybe more expensive chemical is actually going to give them a return in the long run... If you can maybe show them that rotating the chemicals is a good practice to start early to ward off the types of that sort of resistance to other people"

(Sunraysia, information provider)

Certain chemicals such as glyphosate are relatively low cost, which can encourage their continued use. This issue of persistent use of specific chemicals by most land managers in an area is further exacerbated where the choice of alternative herbicides is limited.

"even when people started getting resistance most people went yep, I know if I can change my practices now that's going to delay it, but it's still working, so how about I just keep going until it stops working? [laughs] ... It would be fine if there were a lot of different tools out there which were just as effective, and a similar cost. But when the other tools that are out there are more expensive, come with other management issues which makes it more complex, and generally aren't as effective, that makes it a little bit of a hard sell."

(Darling Downs, information provider)

\subsection{How to Encourage Uptake of AWM of Herbicide Resistance}

Reflections on what an area-wide approach to herbicide resistance management could involve (Q4) included raising awareness about the issue and the extent of the problem, implementing weed management practices that address resistance, and getting diverse stakeholders involved.

\subsubsection{Raising Awareness about Herbicide Resistance}

The most common prerequisite for AWM of herbicide resistance, identified by 10 interviewees, was awareness about resistance as a problem. These interviewees suggested that one aspect of awareness is acknowledgement by all people within the relevant area that resistance is an issue on the land they manage. Currently, it is possible for land managers to ignore herbicide resistance, with one saying that "You can stick your head in the sand fairly well; there's still some people that go, 'Oh, there's no such thing as resistance'."

(Other, grower)

Stakeholders explained that more communication about resistance generally is needed as well as awareness about the current state of herbicide resistance, what contributes to resistance and how weeds develop resistance. One interviewee underscored the importance 
of raising awareness among growers of the shared nature of the problem to reduce feelings of being alone in having and tackling resistance.

"They'll be focusing on their own farms, but it's people realising that they're not the only one that has resistant weeds. It sort of struck me years ago that every irrigation farm has problems with Roundup resistant rye grass.... Probably the awareness is getting out there, but it is surprising that it's just so widespread, and that's probably a reinforcement thing to those people to realise they're not on their own."

(Riverina, information provider)

Testing weeds for resistance was also suggested as a possible tool for improving this awareness. Monitoring of herbicide-resistant weeds both on-farm and at a larger scale was proposed as a way to increase land managers' responsiveness to that weed and contribute to reducing potential for resistance.

\subsubsection{Implementing Weed Management Practices That Address Resistance}

Interviewees underscored the need for multiple effective resistance management strategies to be shared among land managers. For area-wide herbicide resistance management, strategies would need to be relevant to all industries.

"I would have thought the biggest benefit from industries working together would be that sort of warding off resistance sort of thing. Like you don't want weeds in close proximity crossing from one industry to another where they've been subject to resistance in one industry and that gets out in the other and has to change the way they manage it. I think that's the biggest threat in terms of having industries working next to each other."

(Sunraysia, information provider)

The participation of multiple industries working together can be limited because weed presence varies with a crop and a different suite of chemicals are available for use with specific crops.

"when you're talking down to a fence line level, like a boundary fence, I think there needs to be some control there on both sides. If you're in horticulture you don't really care about ryegrass numbers and what the ryegrass might be resistant to, because they just tend to use Gramoxone or Spray.Seed on everything so they don't hurt their trees."

(Sunraysia, grower)

Suggested approaches to sharing herbicide resistance management strategies included relevant trials, and agronomists sharing both research and advice to prevent resistance. Sharing of research was also seen as critical, but interviewees emphasised that this must be conducted differently to how it has been conducted in the past to include discussion of research about resistance and results of testing.

"They're just collecting samples on-farm of potential, well, anything that they might be worried about having herbicide resistance ... But does that specifically encourage people to work together? Probably not. I mean it's inferred, but I don't think it's talked about directly"

(Other, information provider)

The need for a reduction in the delay between awareness of problems via testing and action being taken was also reported, and includes having research shared more promptly. More open communication between land managers is also needed for AWM of herbicide resistance, including sharing information about their resistance issues, resistance testing results and what has worked for them.

"if you've got one person with resistance and they don't tell anyone about it, then everyone else is banging their head up against a wall trying to figure out what it is. When someone in the area could say, "Oh, we've had resistance for three years and we've managed it this way." ... So, I do think it is good for everyone to talk and everyone to discuss their different strategies and management options; what works, what doesn't. Because 
resistance can be expensive, and you don't test all the weeds every year. So, it's a good to get a bit of a feel district-wide and then go from there, I suppose."

(Other, information provider)

\subsubsection{Getting Diverse Stakeholders Involved}

Across the interviews, all stakeholders were identified as needing to be included in plans for AWM of herbicide resistance (Q3 and Q4), as follows: growers, agronomists, suppliers, government departments, industry, neighbouring land managers and home gardeners. Yet, two stakeholders were most frequently named as fundamental to any successful AWM of herbicide resistance in their region, namely growers (14 interviewees) and local governments (9 interviewees). Local governments are responsible for management of minor roadsides, including along district and local roads in the Darling Downs, Riverina and Sunraysia. In each of these three regions, roadsides were perceived by at least one interviewee to be a site where herbicide resistance develops, through councils' management of weeds in those areas.

"if your neighbour's not controlling it [weeds], that could cause you a headache, because their seed just spreads into yours, sort of thing. The same probably goes with council. That's where a lot can come from, is roadsides, and they seem to only spray Roundup and glyphosate, so that could be where the resistance to it initially came from, potentially"

(Darling Downs, information provider)

Two further stakeholders were identified as having a responsibility to develop connections with, or between other stakeholders. Interviewees proposed that industries need to be involved to improve cross-industry communication and to work together. Advisory staff are not only important in their work with growers, but can also connect growers to research.

\section{Discussion}

One of the most notable outcomes of the analysis is that the majority of stakeholders (72 of 84) did not have experience with AWM of herbicide resistance. This is despite most (43 of 84) stakeholders identifying herbicide resistance as a key concern and stakeholders having experience with AWM of other land management issues, such as spray drift, managing insecticide resistance or pest animal management. One possible explanation is that resistance is more mobile in pests than weeds [11]; however, recent evidence indicates that herbicide-resistant weed mobility is significant and requires collective regional responses [32]. These insights raise questions about why there are few collaborative programs for herbicide resistance in Australian cropping systems, and what conditions would be required to enable collective community-based approaches.

We begin our discussion by considering how stakeholders' experiences of AWM of herbicide resistance reflect types of cooperation in other cropping and weed management contexts and how programs could be designed to encourage more collaborative work. We then consider the extent to which our findings about the barriers to AWM of herbicide resistance are consistent with those identified in past research. Finally, we consider how past research on collective action may inform future efforts to introduce AWM of herbicide resistance into cropping regions in Australia.

\subsection{Types of Cooperation for AWM of Herbicide Resistance}

One way of understanding interviewee's views on AWM of herbicide resistance is to consider collaboration as a continuum. For example, Sadoff and Grey [33] argued that there are four types of cooperation as follows: unilateral action, coordination, collaboration and joint action. Graham [12] found similar types of cooperation to exist in management of weeds in Canada. The results from the interviews suggest that most of the existing experiences with and perceptions of how AWM of herbicide resistance could operate (Q4, Q4a, Q4d) represent 'unilateral' and 'coordination' modes of cooperation. In the unilateral mode there is limited communication among actors, but everyone undertakes (herbicide 
resistance) management on their own properties with the resources available to them. Coordination involves communication, notification and information sharing [33].

The sets of activities included in Table 3 indicate that interviewees from within and beyond the case study regions focused on individuals unilaterally working on their farms by complying with herbicide guidelines and changing their herbicides regularly. Interviewees also focused on coordination through sharing information about herbicide-resistant weeds, their spread and management and through participation in research about the extent of herbicide resistance in weeds. Such an emphasis on unilateral and coordination modes of collaboration is consistent with past research on AWM in cropping systems. For example, Legg et al. [14] focused on whether land managers individually removed disease-affected cassava plants and introduced disease free cassava plants, and research by Conlong et al. [16] was centred on growers sharing information about a sugarcane pest, control methods and infestations. These studies found that information sharing contributed to area-wide control of these problems, suggesting that there may be value in establishing AWM testing programs that focus on sharing of knowledge about herbicide resistance among stakeholders. For example, in the US, a community-based program to address herbicide resistance in Palmer amaranth used a weed forum to not only raise awareness of the cross-boundary nature of herbicide resistance, but also encourage all participants to commit to weed control on diverse land types [1].

Alternatively, consideration could be given to developing AWM programs that encourage collaboration or joint action modes of cooperation, which are evident in cropping systems in other countries. For example, Phung et al. [23] described a joint action rat management program in Vietnam where land managers coordinated the timing of pesticide applications and Bouzidi et al. [18] described a joint action program in Morocco where growers pooled resources and shared machinery. In designing an AWM program for herbicide resistance, there should be reflection on whether there is value in going beyond individual best practices and sharing information, i.e., unilateral and coordination modes, to more providing widespread support to one another and even synchronizing the timing of herbicides, which would represent more collaborative and joint modes. In the case of herbicide resistance, there may be an opportunity for growers to collectively purchase weed spray technology, which is often beyond the reach of individual growers, to enable more targeted control of weeds, minimize herbicide use and lower the probability of further herbicide resistance evolving.

\subsection{Addressing Barriers to AWM of Herbicide Resistance}

To further develop AWM of herbicide resistance in Australia, barriers to more collaborative and joint modes of cooperation need to be addressed. Four of the inter-related barriers identified by stakeholders $(\mathrm{Q} 4 \mathrm{~g})$ included diversity of land uses within each region, the time and costs associated with changing herbicide practices, and a lack of willingness to share information about herbicide resistance with others.

Past research on AWM in cropping system assumes that there is a large degree of homogeneity of land use types [11]. The interviewees indicated that although the three regions are characterised as cropping regions, they are far from homogenous. Stakeholders believe such heterogeneity is a barrier to AWM of herbicide resistance because adjoining land managers have different priorities and approaches to managing weeds. Research on collective action more generally has invested considerable effort in investigating whether heterogeneity affects the development of collaboration. Heterogeneity is considered important because it affects whether trust develops among people with diverse interests [34]. In a review of past research, Poteete and Ostrom [34] found that not all types of heterogeneity are problematic for all forms of collective action. Instead, what is important is the design of the institutions that influence the work being done collectively. It is possible for institutions to be designed to help more heterogenous groups identify complementarities that build a stronger foundation for collective action. Thus, when designing a program for AWM of herbicide resistance, consideration needs to be given to building working relationships 
among stakeholders with diverse interests and looking for areas of shared interest and concern that overcome difference and disagreement [1].

In addition to the heterogeneity of land users, interviewees were also concerned about the extent to which land managers have time and resources to invest in AWM of herbicide resistance. The concern about time is consistent with past research on AWM in cropping systems. For example, Ervin et al. [13] found that time constraints served as a barrier to both concern for herbicide resistance migrating from nearby lands and the belief that cooperation is necessary for effective resistance management. From a different perspective, Phung et al. [23] found that collective rat control, such as hunting, was perceived to be more time consuming compared to use of chemical baits, thereby constraining collaborative pest management by hunting. Thus, there is a need to demonstrate whether AWM of herbicide resistance provides benefits with respect to reducing the amount of time needed to be invested in weed management over the short and long term.

Costs were discussed by interviewees in a different way to the descriptions presented in past research. Some interviewees discussed the long-term costs associated with losing the cheapest chemical option, glyphosate, because of herbicide resistance, whereas past research on AWM in cropping systems has focused on growers' current financial capacity to participate in cooperative programs. For example, previous research has found that growers with larger properties or with a higher annual farm income are less likely to participate in collective action [20,35]. Similarly, Ervin et al. [13] found that average state cropland farm size had a significant negative effect on whether growers had discussed the problem of herbicide-resistant weeds with adjoining or nearby land managers. Smaller growers may have more scope for interaction with other farmers and receive relatively greater financial benefits from the others' participation in AWM [35]. Past research suggests that AWM of herbicide resistance may benefit from targeting smaller growers, who may be more likely to participate in AWM and receive greater relative benefits from participation. Our research identifies the need to also consider the long-term impacts associated with changing herbicides.

Finally, growers may also feel hesitant to communicate about problems such as herbicide resistance on their property. Australian farmers may avoid discussing issues on their property because their farming ability can inform their respectability within their community [36]. Social norms that encourage farmers to work and learn independently can also limit farmers' communication about weed problems [37]. Communication is a precursor to collective action as a means of developing common knowledge about the social-ecological system, how individual actions affect others, the benefits of cooperating [38] and the development of shared goals [39]. Additionally, both communication with other land managers about herbicide-resistant weeds [13] and shared goals [1] have been recognised to be requirements for management of herbicide resistance. Therefore, barriers to communication must be addressed for AWM of herbicide resistance to develop and be sustained.

\subsection{Conditions Needed for AWM of Herbicide Resistance}

Existing research has identified a range of conditions that need to be met for groups to work together to manage landscape-scale weed management challenges. For management of herbicide resistance, these include the following: land managers being concerned about herbicide-resistant weeds migrating from nearby lands; communication with other land managers about herbicide-resistant weeds; belief that cooperation is needed for effective resistance management [13]; clearly defined boundaries of the area and people involved; agreement to a shared goal; provision of resources to those land managers with fewer resources; strong working relationships or shared values among land managers [1]. At present, none of these conditions can be wholly met in cropping regions in Australia, which may explain why few stakeholders have been involved in AWM programs to date.

Interviewees emphasised the need for more awareness and communication about herbicide resistance, and having more, diverse stakeholders working together in any AWM of herbicide resistance (Q3 and Q4). In the sections above, we have outlined how programs 
designed to encourage AWM of herbicide resistance could focus on sharing information about the nature of the herbicide resistance problem, offer testing to raise awareness about the extent and spread of herbicide resistance, pool resources, and develop strong working relationships. Such program designs would address some of these enabling conditions. However, past research also suggests that AWM of herbicide resistance programs would also need to clearly define boundaries across which the program would operate and establish a shared goal among participants. For example, Ervin and Frisvold [11] recommend developing moderate size AWM systems that are not so large that it is difficult to assemble and share knowledge, and that are not so small that they do not provide sufficient benefits to encourage participation.

\section{Conclusions}

Herbicide resistance is the most common weed management concern among diverse stakeholders from geographically distant cropping regions of Australia, yet AWM of herbicide resistance predominantly exists only in theory, rather than practice. There is much research yet to be done to understand whether the views of the stakeholders interviewed are representative of the broader cropping communities and, if so, why there is such a broad knowledge-action gap between understanding the need for collective action and timely practice on-ground. There is also an opportunity for government agencies, industry groups and other interested actors to take the lead on an AWM initiative, given the underlying interest in the idea from diverse stakeholders. Commencement of AWM may involve identifying a medium-sized and clearly defined area in which to map out the extent of herbicide-resistant weeds, developing a shared goal, fostering working relationships, and then practicing joint activities to evaluate and demonstrate the financial and other benefits that result. If such benefits are evident, this example may provide the momentum and inspiration for herbicide resistance management within and across cropping regions, as has occurred for other, international area-wide issues.

Supplementary Materials: The following are available online at https: / www.mdpi.com/article/ 10.3390 /su14031793/s1, Table S1. Interview questions related to herbicide resistance management for growers $(\mathrm{G})$, public or communal land managers $(\mathrm{P})$, weed management advisors, agronomists, industry representatives, researchers and government staff $(\mathrm{W})$.

Author Contributions: Conceptualization, S.G. and G.H.; methodology, L.B., S.G., G.H. and S.M.; formal Analysis, L.B., R.C., S.G., G.H., K.H. and S.S.; investigation, L.B., S.G., G.H., K.H. and S.M.; resources, S.G.; data curation, L.B., R.C., S.G., G.H., K.H., S.M. and S.S.; writing-original draft preparation, K.H., S.G. and G.H.; writing-review and editing, R.C., S.G., G.H., K.H. and S.S.; supervision, S.G. and G.H.; project administration, S.G. and G.H.; funding acquisition, S.G. All authors have read and agreed to the published version of the manuscript.

Funding: This research was funded by the Australian Government Department of Agriculture, Water and the Environment as part of its Rural R\&D for Profit program grant number 133002.

Institutional Review Board Statement: The study was approved by the Social Science Human Research Ethics Committee of the CSIRO (077/20, 26 June 2020) and the Human Research Ethics Committee of the University of Wollongong (2020/285, 5 August 2020).

Informed Consent Statement: Informed consent was obtained from all subjects involved in the study.

Acknowledgments: The project involves 11 research and development partners, as follows: Grains Research and Development Corporation, Cotton Research and Development Corporation, AgriFutures Australia, CSIRO, University of Queensland, University of Adelaide, University of Wollongong, Mallee Sustainable Farming, Millmerran Landcare Group, Irrigation Research \& Extension Committee Inc and the Toowoomba Regional Council. We thank all the participants who were interviewed for their time. Sonia Graham would like to acknowledge the support of an Australian Research Council Discovery Early Career Research Award DE200100234.

Conflicts of Interest: The authors declare no conflict of interest. 


\section{References}

1. Bagavathiannan, M.V.; Graham, S.; Ma, Z.; Barney, J.N.; Coutts, S.R.; Caicedo, A.L.; De Clerck-Floate, R.; West, N.M.; Blank, L.; Metcalf, A.L. Considering weed management as a social dilemma bridges individual and collective interests. Nat. Plants 2019, 5, 343-351. [CrossRef] [PubMed]

2. Peterson, M.A.; Collavo, A.; Ovejero, R.; Shivrain, V.; Walsh, M.J. The challenge of herbicide resistance around the world: A current summary. Pest Manag. Sci. 2018, 74, 2246-2259. [CrossRef] [PubMed]

3. Heap, I. The International Herbicide-Resistant Weed Database. Available online: www.weedscience.org (accessed on 15 November 2021).

4. $\quad$ Llewellyn, R.S.; Lindner, R.K.; Pannell, D.J.; Powles, S.B. Herbicide resistance and the adoption of integrated weed management by Western Australian grain growers. Agric. Econ. 2007, 36, 123-130. [CrossRef]

5. Llewellyn, R.; Ronning, D.; Ouzman, J.; Walker, S.; Mayfield, A.; Clarke, M. Impact of Weeds on Australian Grain Production: The Cost of Weeds to Australian Grain Growers and the Adoption of Weed Management and Tillage Practices; Grains and Research Development Corporation: Canberra, Australia, 2016.

6. Pannell, D.J.; Tillie, P.; Rodríguez-Cerezo, E.; Ervin, D.; Frisvold, G.B. Herbicide resistance: Economic and environmental challenges. AgBioForum 2016, 19, 136-155.

7. Nguyen, H.T.; Malone, J.M.; Boutsalis, P.; Preston, C. Genetic diversity of glyphosate resistant Echinochloa colona. J. Res. Weed Sci. 2020, 3, 145-161. [CrossRef]

8. Lu, Y.; Baker, J.; Preston, C. The spread of resistance to acetolactate synthase inhibiting herbicides in a wind borne, self-pollinated weed species, Lactuca serriola L. Theor. Appl. Genet. 2007, 115, 443-450. [CrossRef]

9. Llewellyn, R.S.; Allen, D.M. Expected mobility of herbicide resistance via weed seeds and pollen in a Western Australian cropping region. Crop Prot. 2006, 25, 520-526. [CrossRef]

10. Coutts, S.R.; Yokomizo, H.; Buckley, Y.M. The behavior of multiple independent managers and ecological traits interact to determine prevalence of weeds. Ecol. Appl. 2013, 23, 523-536. [CrossRef]

11. Ervin, D.E.; Frisvold, G.B. Community-based approaches to herbicide-resistant weed management: Lessons from science and practice. Weed Sci. 2016, 64, 609-626. [CrossRef]

12. Graham, S. Coordinating invasive plant management among conservation and rural stakeholders. Land Use Policy 2019, 81, 247-255. [CrossRef]

13. Ervin, D.E.; Breshears, E.H.; Frisvold, G.B.; Hurley, T.; Dentzman, K.E.; Gunsolus, J.L.; Jussaume, R.A.; Owen, M.D.; Norsworthy, J.K.; Al Mamun, M.M. Farmer attitudes toward cooperative approaches to herbicide resistance management: A common pool ecosystem service challenge. Ecol. Econ. 2019, 157, 237-245. [CrossRef]

14. Legg, J.; Ndalahwa, M.; Yabeja, J.; Ndyetabula, I.; Bouwmeester, H.; Shirima, R.; Mtunda, K. Community phytosanitation to manage cassava brown streak disease. Virus Res. 2017, 241, 236-253. [CrossRef] [PubMed]

15. Fuchs, T. Insect management in the Texas eradication zones: A progress report. In Proceedings of the 1999 Beltwide Cotton Conferences, Orlando, FL, USA, 3-7 January 1999; pp. 824-828.

16. Conlong, D.E.; Webster, T.; Wilkinson, D. Ten years of area-wide integrated pest management with a push-pull component against Eldana saccharina (Lepidoptera: Pyralidae) in sugarcane in the Midlands North region of KwaZulu-Natal. In Proceedings of the Annual Congress-South African Sugar Technologists' Association, Durban, South Africa, 16-18 August 2016; pp. 70-84.

17. Yasuoka, J.; Levins, R.; Mangione, T.W.; Spielman, A. Community-based rice ecosystem management for suppressing vector anophelines in Sri Lanka. Trans. R. Soc. Trop. Med. Hyg. 2006, 100, 995-1006. [CrossRef] [PubMed]

18. Bouzidi, Z.; Faysse, N.; Kuper, M.; Billaud, J.-P. Investigating the invisible roots of a prevailing narrative of farmers' failed collective action in Morocco. J. N. Afr. Stud. 2020, 25, 342-362. [CrossRef]

19. Damayanti, M.; Nugroho, P.; Tyas, W.P. Norms in community-based organic farming. Agriculture 2018, 8, 185. [CrossRef]

20. Stallman, H.R.; James, H.S., Jr. Determinants affecting farmers' willingness to cooperate to control pests. Ecol. Econ. 2015, 117, 182-192. [CrossRef]

21. Stallman, H.R.; James, H.S., Jr. Farmers' willingness to cooperate in ecosystem service provision: Does trust matter? Ann. Public Coop. Econ. 2017, 88, 5-31. [CrossRef]

22. Palis, F.G.; Singleton, G.R.; Brown, P.R.; Huan, N.H.; Umali, C.; Nga, N.T.D. Can humans outsmart rodents? Learning to work collectively and strategically. Wildl. Res. 2011, 38, 568-578. [CrossRef]

23. Phung, N.T.M.; Brown, P.R.; Leung, L.K. Use of computer simulation models to encourage farmers to adopt best rodent management practices in lowland irrigated rice systems in An Giang Province, the Mekong Delta, Vietnam. Agric. Syst. 2013, 116, 69-76. [CrossRef]

24. Australian Bureau of Statistics. Agricultural Commodities, Australia, 2019-2020 Financial Year. Available online: https://www. abs.gov.au/statistics/industry/agriculture/agricultural-commodities-australia/latest-release (accessed on 5 October 2021).

25. Australian Bureau of Statistics. Agricultural Commodities, Australia. Available online: https://www.abs.gov.au/statistics/ industry/agriculture/agricultural-commodities-australia (accessed on 5 October 2021).

26. Australian Bureau of Statistics. Value of Agricultural Commodities Produced, Australia. Available online: https://www.abs.gov. $\mathrm{au} /$ statistics/industry/agriculture/value-agricultural-commodities-produced-australia (accessed on 13 December 2021).

27. Stenekes, N.; Kancans, R. Pest Animals and Weed Management Survey. Available online: https: / / www.awe.gov.au/abares/ research-topics/social-sciences/pest-animals-weed-management-survey (accessed on 5 October 2021). 
28. Bryman, A. Social Research Methods, 5th ed.; Oxford University Press: Oxford, UK, 2016.

29. Braun, V.; Clarke, V. Using thematic analysis in psychology. Qual. Res. Psychol. 2006, 3, 77-101. [CrossRef]

30. Neale, J. Iterative categorization (IC): A systematic technique for analysing qualitative data. Addiction 2016, 111, 1096-1106. [CrossRef] [PubMed]

31. Baxter, J.; Eyles, J. Evaluating qualitative research in social geography: Establishing 'rigour' in interview analysis. Trans. Inst. Br. Geogr. 1997, 22, 505-525. [CrossRef]

32. Beckie, H.J.; Gulden, R.H.; Shaikh, N.; Johnson, E.N.; Willenborg, C.J.; Brenzil, C.A.; Shirriff, S.W.; Lozinski, C.; Ford, G. Glyphosate-resistant kochia (Kochia scoparia L. Schrad.) in Saskatchewan and Manitoba. Can. J. Plant Sci. 2015, 95, 345-349. [CrossRef]

33. Sadoff, C.W.; Grey, D. Cooperation on international rivers: A continuum for securing and sharing benefits. Water Int. 2005, 30, 420-427. [CrossRef]

34. Poteete, A.R.; Ostrom, E. Heterogeneity, group size and collective action: The role of institutions in forest management. Dev. Chang. 2004, 35, 435-461. [CrossRef]

35. Brown, Z.S. Voluntary programs to encourage refuges for pesticide resistance management: Lessons from a quasi-experiment. Am. J. Agric. Econ. 2018, 100, 844-867. [CrossRef]

36. Phillips, E. Social and cultural factors that influence the adoption of sustainable farm practices. In Case Studies in Increasing the Adoption of Sustainable Resource Management Practices; Shulman, A.D., Price, R.J., Eds.; Land and Water Resources Research and Development Corporation: Canberra, Australia, 2000; pp. 46-56.

37. Height, K. The Role of Social Norms in Collective Action for Weed Management across Rural Private Property. Ph.D. Thesis, University of Melbourne, Melbourne, Australia, 2018.

38. Ostrom, E. A general framework for analyzing sustainability of social-ecological systems. Science 2009, 325, 419-422. [CrossRef]

39. Rist, S.; Chidambaranathan, M.; Escobar, C.; Wiesmann, U.; Zimmermann, A. Moving from sustainable management to sustainable governance of natural resources: The role of social learning processes in rural India, Bolivia and Mali. J. Rural Stud. 2007, 23, 23-37. [CrossRef] 